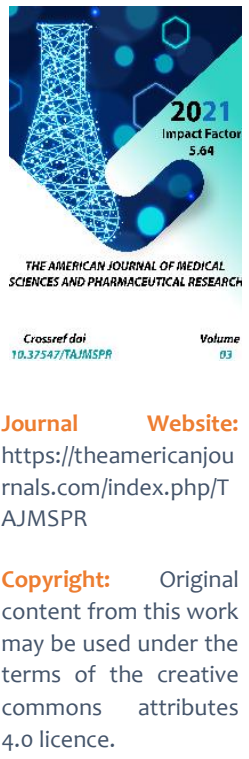

\title{
Some Structural Features Of The Prevalence Of Disability And Kaitian Disability In Khorezm Province From Hypertension
}

\author{
Ruzmetov Bazirgon Shokirovich \\ Department Of Faculty And Hospital Therapy, Urgench Branch, Tashkent Medical Academy, \\ Uzbekistan
}

\section{ABSTRACT}

Diseases of the circulatory system are considered one of the most urgent problems of the health system in all countries of the world, and one of its leading diseases - arterial blood pressure, with its relatively severe complications, is distinguished from other diseases of the same system. In the following years, in many developed countries of the world, including Uzbekistan, the main share of causes of death is being persecuted for diseases of the circulatory system. In European countries, this figure is $48 \%$ (in men - 43\%, in women - 55\%), in Uzbekistan, this is in the 2009 year.It is noted that from diseases (ischemic heart disease) to $50,1 \%$, from hypertension to $17,7 \%)-20,8 \%[1,3]$.

\section{KEYWORDS}

Arterial blood pressure, Khorezm province, hypertension is a disability.

\section{INTRODUCTION}

The author notes that although the death rate in relation to some independent Commonwealth Countries - Russia, Ukraine, Kazakhstan-is somewhat lower, many European countries are higher than Germany, France, Sweden and other countries. It can also be seen from the above information that a significant level of salivation of diseases of the circulatory system is associated with hypertension, and this disease has its own peculiarities-with some possible complications. We know from extensive literature and statistical data that one of the main medical, social, socio-psychological and economic complications of hypertension is disability $[2,6]$. Judging from some scientific findings, disability from $\mathrm{AH}$ is characterized by an increase in many states in the following years. 
The scientific findings of E.A. Turusheva (2017) show that in Russia up to $40 \%$ of adults, up to $25 \%$ of young people suffer from arterial hypertension, which is the leading risk factor for circulatory system diseases and in most cases is noted to result in disability and death.

The serious socio-economic significance of the problem lies in the fact that in Russia it is at the age of $45-50$ years that $20 \%$ of the population are recognised as disabled due to this disease, with more than $30 \%$ of cases being fatal [].

\section{PURPOSE OF THE STUDY}

To determine some specific features of the prevalence of primary disability and rediscovered disability due to arterial pressure disease in Khorezm province.

According to some statistics provided by the regional cardiology centre, the incidence of blood pressure tends to increase. While in 2017, blood pressure accounted for $28.8 \%$ of all circulatory system diseases, in 2018 it was $41.9 \%$. As you can see, the number of visits to the cardiologist's office has increased by $45.5 \%$ in one year. According to a scientific study by U.K Ahmadalieva et al(2016) in Andijan, among the male population aged 15-70 years and older, moderate blood pressure are most common(72.6\%), compared to it in $2.6 \%$ caseslow moderate blood pressure (27.9\%) and severe blood pressure in $24.5 \%$. Most importantly, one in three men has an indication for primary, secondary and tertiary prevention aimed at preventing blood pressure. In a population of men and women, depending on their age, there is an increase in blood pressure of up to 7.5 times in young people and a predominance of 11 major risk factors in men and 9 in women.

Cardiovascular diseases, including AKI, continue to be the leading cause of mortality among the Uzbek population. In 2013, the standardised mortality rate from upper respiratory diseases was 49.1 and from tumours 37.5 .

In the analysis of the prevalence of arterial hypertension among the rural population of the region, as a result of its division into 2 groups, the users of the first highly mineralized water and the second low mineralized water, in the first group arterial hypertension was revealed in $71.2 \%$ of people aged $61-74$ years, 36 60 years - in $68.4 \%, 22-35$ years - in $26.9 \%, 18-21$ years - in $5.3 \%$, in the second group - $51.6 \%$, 42.7 $12.8 \%$ and $0.5 \%$ respectively.

\section{MATERIALS AND RESEARCH METHODS}

In order to study disability from arterial pressure disease in the region in two rural TPPs of Khazarasp district (750 units) and Yangibazar district (626 units) and one city of Urgench (817 units) by obtaining extracts from disability records identified in 2016-2020, reporting forms No 2193 and No 7 were analyzed, a total of 144 in average, including 57 were studied and evaluated newly registered disabilities from the disease. All socio-hygienic and sanitary-statistical methods were widely used in the statistical analysis of the data obtained.

\section{RESEARCH RESULTS}

The level and composition of primary, recurrent and total disability were analyzed simultaneously in the studied statistical complexes. The primary disability accounts for $30.3 \%$ of the total disability in Urgench city and accounts for $18.1 \pm 0.44$ per 10,000 population. The rate of the rural population is $14.5 \%$ (15.0 \pm 0.13$)$ in Yangibazar district and 20.1\% $(10.1 \pm 0.07)$ in Khazarasp district. While total disability is $25.6 \%$ due to circulatory system diseases, the rate of hypertension is $28.3 \%$ due 
to circulatory system diseases. Of the total number of registered disabilities due to hypertension, $85.7 \%$ were repeated, i.e. re- discovered, disabilities and $14.3 \%$ were primary disabilities of patients.

Table 1. Primary disability prevalence rate in urban and rural areas of Khorezm province from SDP in 2016-2020 (10,000 residents) $(P \pm m)$

\begin{tabular}{|c|c|c|c|c|c|c|c|}
\hline \multirow{2}{*}{$\begin{array}{l}\text { Areas } \\
\text { studied }\end{array}$} & \multirow{2}{*}{$\begin{array}{c}\text { Diseases } \\
\text { in an } \\
\text { absolute } \\
\text { number }\end{array}$} & \multicolumn{2}{|c|}{ Sex } & \multicolumn{3}{|c|}{ Disability groups } & \multirow{2}{*}{ Total } \\
\hline & & Male & Female & I-Group & II-Group & III-group & \\
\hline $\begin{array}{l}\text { Urgench } \\
\text { city }\end{array}$ & 248 & $22,1 \pm 1,80$ & $14,1 \pm 1,42$ & $0,5 \pm 0,60$ & $16,8 \pm 1,10$ & $8,0 \pm 0,76$ & $18,1 \pm 0,44$ \\
\hline $\begin{array}{c}\text { Yangibazar } \\
\text { district }\end{array}$ & 98 & $13,5 \pm 1,14$ & $16,4 \pm 1,81$ & - & $13,1 \pm 1,41$ & $1,8 \pm 0,27$ & $15,0 \pm 0,13$ \\
\hline $\begin{array}{c}\text { Khazarasp } \\
\text { district }\end{array}$ & 155 & $15,9 \pm 1,46$ & $4,4 \pm 0,58$ & $0,3 \pm 0,14$ & $9,4 \pm 0,79$ & $0,3 \pm 0,14$ & $10,1 \pm 0,07$ \\
\hline
\end{tabular}

As can be seen, disability from arterial pressure disease in urban areas is 1.4 times higher than in rural areas, men in Urgench city 1.6 times higher than women in rural areas, especially in Khazarasp district 3.6 times higher. In the Yangibazar district, the opposite is true, i.e. disability among women is slightly higher. Group I disability is $5.5 \%$ of total disability in the city, group III - $44.2 \%$ and group II $-50.3 \%$. If we look at this situation among rural residents, in Yangibazar district group I disability was not registered at all during the studied 5 years. It is established that $87,3 \%$ of disability is group II and $12 \%$ - group III, and in Khazarasp district
$93,0 \%$ of total disability is group II. A shorter conclusion is that due to arterial pressure disease, the primary patients go to group II disability, which means that patients are completely and permanently disabled and cannot seek help from a foreigner on their own. It is noteworthy that in Urgench city the primary disability is higher than in Hazarasp district - 1.8 and in Yangibazar district - 1.2 times (Table-1). In all regions where the primary disability from arterial pressure was studied, the increase in age was observed in the period from 60 years old. 
Table 2. Prevalence of newly diagnosed disability from hypertension in urban and rural areas of Khorezm region in 2016-2020 by gender (per 10000 population) $(\mathrm{P} \pm \mathrm{m})$ year ....

\begin{tabular}{|c|c|c|c|c|}
\hline \multirow{2}{*}{ № } & Place of residence & \multicolumn{2}{|c|}{ Sex } & \multirow{2}{*}{ All } \\
\cline { 3 - 4 } & & Male & Female & \\
\hline 1 & In the city & $3.5 \pm 0.71$ & $4.2 \pm 0.78$ & $4.1 \pm 0.54$ \\
\hline 2 & In the countryside & $3.0 \pm 0.52$ & $4.3 \pm 0.63$ & $4.05 \pm 0.43$ \\
\hline & All & $3.5 \pm 0.20$ & $4.1 \pm 0.48$ & $4.1 \pm 0.34$ \\
\hline
\end{tabular}

As can be seen, disability from arterial pressure disease in urban areas is 1.4 times higher than in rural areas, men in Urgench city 1.6 times higher than women in rural areas, especially in Khazarasp district 3.6 times higher. In the Yangibazar district, the opposite is true, i.e. disability among women is slightly higher. Group, I disability is $5.5 \%$ of total disability in the city, group III - $44.2 \%$ and group II - 50.3\%. If we look at this situation among rural residents, in Yangibazar district group I disability was not registered at all during the studied 5 years. It is established that $87,3 \%$ of disability is group II and $12 \%$ - group III, and in Khazarasp district $93,0 \%$ of total disability is group II. Notably, it was found that the number of re-diagnosed disabilities caused by hypertension in both men and women was almost the same average of $30-31 \%$ of the total number of identified circulatory system disorders. This means that hypertension has a greater weight among circulatory system disorders. Separately, it is worth noting that newly detected disability from hypertension has a pattern of increase over the years studied. (2016-135ta, 2020-155ta) we can note that this condition is especially noticeable in men (by 20\%). As we know, disability is not analyzed in detail in all age groups in statistical reports. Under 39 years old and 40-55 years old in women, 40-60 years old in men, as well as in the age groups of disability from childhood. some features become apparent when we analyze the newly detected disorders from hypertension with these very age groups. A total of $4.9 \%$ of the reported recurrent disorders were under age 39 and $95.1 \%$ were over age 40 , with a prevalence of $0.27 \pm 0.12$ and $27.6 \pm 2.35$ for every 10,000 patients of the same age, respectively.

Table 3. revalence of primary disability by age of patients (Per 10,000 inhabitants) $(\mathrm{P} \pm \mathrm{m})$

\begin{tabular}{|c|c|c|c|c|c|c|c|}
\hline Learned & \multirow[b]{2}{*}{ Sex } & \multicolumn{6}{|c|}{ Young people } \\
\hline & & $\begin{array}{l}20 \text { up } \\
\text { to age }\end{array}$ & $21-30$ & $31-40$ & $41-50$ & $51-60$ & $60<$ \\
\hline \multirow{2}{*}{ Urgench city } & Male & - & - & $0,3 \pm 0,02$ & $37,1 \pm 1,3$ & $181,8 \pm 3,42$ & $85,6 \pm 1,84$ \\
\hline & Female & - & - & $2,7 \pm 0,32$ & $59,5 \pm 2,0$ & $106,1 \pm 2,42$ & $11,6 \pm 0,94$ \\
\hline
\end{tabular}




\begin{tabular}{|c|c|c|c|c|c|c|c|}
\hline \multirow{2}{*}{$\begin{array}{c}\text { Yangibazar } \\
\text { district }\end{array}$} & Male & - & - & $6,7 \pm 0,64$ & $81,6 \pm 2,41$ & $63,6 \pm 1,84$ & \\
\cline { 2 - 8 } & Female & - & - & $22,5 \pm 1,44$ & $92,8 \pm 2,57$ & $67,6 \pm 1,96$ & $11,9 \pm 0,76$ \\
\hline \multirow{2}{*}{$\begin{array}{c}\text { Khazarasp } \\
\text { district }\end{array}$} & Male & - & $0,84 \pm 0,02$ & $1,2 \pm 0,06$ & $42,3 \pm 1,75$ & $137,9 \pm 3,76$ & $-26,2 \pm 1,70$ \\
\cline { 2 - 8 } & Female & - & $0,8 \pm 0,02$ & $0,8 \pm 0,02$ & $20,2 \pm 0,75$ & $26,0 \pm 1,65$ & $8,5 \pm 0,76$ \\
\hline \multirow{2}{*}{ All } & Male & - & $0,28 \pm 0,03$ & $2,73 \pm 0,35$ & $53,7 \pm 2,41$ & $127,7 \pm 3,56$ & $41,2 \pm 1,75$ \\
\cline { 2 - 8 } & Female & - & $0,28 \pm 0,03$ & $8,66 \pm 1,2$ & $57,5 \pm 2,34$ & $66,5 \pm 1,99$ & $6,7 \pm 0,51$ \\
\hline
\end{tabular}

Primary disability is almost not recorded until the age of 30 years, without taking into account the Khazarasp district. In it, this accounted for only $5.3 \%$ of the total disability. In the distribution of primary disability in young people, some specific characteristics were identified. Primary disability is relatively high in males in general but is relatively high in females in most cases between the ages of 31-40 and 4150. But at the age of $51-60$ years, primary disability sharply increased in men, so on account of this, it can be noted that the disability in men has increased to a higher level.
It is noteworthy that disability from arterial blood pressure is 3,2 times higher than in men, especially in women aged 31-40 years. In both cases, the highest index of primary disability was observed at the age of 51-60 years. (Table2) It was noted that re-disability from arterial blood pressure accounted for $78,3 \%$ of total disability and is equal to an average of $56,7 \pm 2,19$ for every 10000 population in the studied regions. This figure was 2 marotaba higher than Urgench city and Khazarasp district in the Newbazar district and equal to $88.6 \pm 3.66$ for every 10000 population.

Table 4 The rate of prevalence of disability, which is determined again from hypertension, by the age of patients (to 10000 inhabitants) $(\mathrm{P} \pm \mathrm{m}$ )

\begin{tabular}{|c|c|c|c|c|c|c|}
\hline \multirow{2}{*}{$\begin{array}{c}\text { Place of } \\
\text { residence }\end{array}$} & \multicolumn{5}{|c|}{ Young people } \\
\cline { 2 - 7 } & Total & Male & Female & Female & $\begin{array}{c}\text { male (40- } \\
60 \text { years) }\end{array}$ & $\begin{array}{c}\text { female (40- } \\
55 \text { years) }\end{array}$ \\
\cline { 2 - 7 } & & $0.21 \pm 0.02$ & $0.43 \pm 0.10$ & $28.5 \pm 3.83$ & $25.8 \pm 4.87$ & $30.7 \pm 6.01$ \\
\hline In the city & $0.32 \pm 0.10$ & & & & \\
\hline
\end{tabular}




\begin{tabular}{|c|c|c|c|c|c|c|}
\hline $\begin{array}{c}\text { In the } \\
\text { village }\end{array}$ & $0.30 \pm 0.07$ & & $0.23 \pm 0.04$ & $27.4 \pm 3.0$ & $25.3 \pm 4.35$ & $29.7 \pm 4.72$ \\
\hline Total & $0.27 \pm 0.10$ & $0.07 \pm 0.02$ & $0.30 \pm 0.15$ & $27.6 \pm 2.35$ & $27.3 \pm 3.12$ & $27.6 \pm 3.55$ \\
\hline
\end{tabular}

As you can see, (Table 2) hypertension is most common after the age of 40 , in both men and women. Recurrent disability after the age of 40 is more than 100 times higher than before the age of 39. Hence, this necessitates a greater focus on primary prevention at that age, and the role of socio-medical, biological and other factors contributing to the condition should be explored and identified. It has been established that the rate of disability among women under the age of 39 is 4.3 times higher than among men, while after the age of 40 it is practically the same. This fact needs to be analysed in women specifically in relation to their reproductive activity.

Table 5 Re-disability from arterial blood pressure in the Khorezm region Prevalence rate in 20162020 years (to 10000 inhabitants) $(P \pm m)$

\begin{tabular}{|c|c|c|c|c|c|c|c|}
\hline \multirow{2}{*}{ Areas studied } & \multirow{2}{*}{$\begin{array}{c}\text { Disabled } \\
\text { (absolute } \\
\text { number) }\end{array}$} & Male & Female & I-group & II- group & $\begin{array}{c}\text { III- } \\
\text { group }\end{array}$ & Total \\
\cline { 3 - 7 } & 569 & $45,1 \pm 2,57$ & $38,0 \pm 2,34$ & $1,0 \pm 0,02$ & $32,9 \pm 1,54$ & $7,3 \pm 0,72$ & $41,5 \pm 1,73$ \\
\hline Urgench city & 578 & $128,5 \pm 3,76$ & $49,5 \pm 2,78$ & $0,6 \pm 0,30$ & $80,6 \pm 3,50$ & $7,3 \pm 1,05$ & $88,6 \pm 3,66$ \\
$\begin{array}{c}\text { Yangibazar } \\
\text { district }\end{array}$ & 599 & $52,4 \pm 2,65$ & $28,1 \pm 1,37$ & $0,9 \pm 0,24$ & $38,1 \pm 1,59$ & $1,0 \pm 0,25$ & $40,1 \pm 1,63$ \\
\hline $\begin{array}{c}\text { Khazarasp } \\
\text { district }\end{array}$ & 5 & & & & & & \\
\hline
\end{tabular}

The analysis showed that in the studied regions with repeated disability, on average, 1.9 marotabas higher than for women in men. This position was equal to -1.2 in Urgench, 2.6 ha in Novi and 1.9 ha in Hazarasp district. This means that arterial vascular disease is almost twice as common. Traditionally, the main disability was registered in the second group, and it was determined that in Urgench city - 79.2\%, in Newbazar district - $90.97 \%$ and in Khazarasp 
district - 95.0\%. This means that the majority of patients are considered to be those who are completely and permanently inactive. (Table 3) As the age of patients increased, repeat disability also persisted as a feature of the increase in primary disability before the age of 60 , and its highest rate was observed between the ages of 51-60. Only in the Newcomer's Dune District were men excluded, in which the high rate of disability was recorded between the ages of 41-50 years, and there were 820.2 for every 10000 at the same age. Blood pressure one feature of disability in disease is that even one of the disabilities noted in the regions studied is not working, although it is known from much of the literature that in some foreign countries blood pressure is used by patients because of their ability to work. Total disability from blood pressure disorders in the region is $71.1 \pm 2.45$ per 10,000 inhabitants in the regions we studied selectively. When we saw this indicator in the cross-section of the studied areas, we found out that its highest level was in Yangibazar district and was 103.6 \pm 3.96 , while in Khazarasp district (50.2 \pm 1.83 ) it was 2 and in Urgench district $(59.6 \pm 2.08)$ it was 1.7 times higher. The total average disability in rural areas $(76.9 \pm 2.66)$ is $29.0 \%$ higher than in urban areas.

Table 6 Prevalence of pre-disability from hypertension by disability groups (10000 population) $(\mathrm{P} \pm \mathrm{m})$

\begin{tabular}{|c|c|c|c|c|c|c|c|c|c|}
\hline \multirow[b]{2}{*}{$\begin{array}{c}\text { Habita } \\
\text { t }\end{array}$} & \multicolumn{3}{|c|}{ Male } & \multicolumn{3}{|c|}{ Female } & \multicolumn{3}{|c|}{ Total } \\
\hline & $\begin{array}{c}\mathrm{I}- \\
\text { grou } \\
\mathrm{p}\end{array}$ & II- group & $\begin{array}{l}\text { III- } \\
\text { group }\end{array}$ & $\begin{array}{c}\mathrm{I}- \\
\text { grou } \\
\mathrm{p}\end{array}$ & II- group & $\begin{array}{l}\text { III- } \\
\text { group }\end{array}$ & $\begin{array}{c}\mathrm{I}- \\
\text { grou } \\
\mathrm{p}\end{array}$ & $\begin{array}{c}\text { II- } \\
\text { grou } \\
\text { p }\end{array}$ & $\begin{array}{l}\text { III- } \\
\text { group }\end{array}$ \\
\hline City & - & $\begin{array}{c}3.4 . \\
\pm 0.71 \\
\end{array}$ & $\begin{array}{c}0.15 \pm 0.0 \\
4\end{array}$ & - & $4.1 \pm 0.77$ & $\begin{array}{c}0.28 \pm 0.0 \\
7\end{array}$ & & $\begin{array}{c}3.9 \pm 0 \\
.53\end{array}$ & $\begin{array}{c}0.21 \pm 0 \\
.01\end{array}$ \\
\hline Village & - & $\begin{array}{c}3.21 \pm 0.5 \\
5\end{array}$ & $\begin{array}{c}0.57 \pm 0.1 \\
7\end{array}$ & - & $3.3 \pm 0.54$ & $\begin{array}{c}0.73 \pm 0.7 \\
5\end{array}$ & - & $\begin{array}{l}3.21 \pm \\
0.38\end{array}$ & $\begin{array}{c}0.74 \pm 0 \\
.18\end{array}$ \\
\hline Total & - & $\begin{array}{c}3.50 \pm 0.4 \\
4\end{array}$ & $\begin{array}{c}0.40 \pm 0.1 \\
5\end{array}$ & - & $\begin{array}{c}3.55 \pm 0.4 \\
4\end{array}$ & $\begin{array}{c}0.56 \pm 0.1 \\
7\end{array}$ & - & $\begin{array}{c}3.55 \pm \\
0.31\end{array}$ & $\begin{array}{c}0.54 \pm 0 \\
.12\end{array}$ \\
\hline
\end{tabular}

Several features were also noted when examining the results of the analysis of newly diagnosed hypertension-related impairments by disability group. Of the total number of people with disabilities, $86.8 \%$ are group II and $13.2 \%$ are group III disabled, and it is noteworthy that group I disabled people are not registered at all. Looking separately at the most prevalent group II disability, in urban areas its prevalence is slightly higher for women $(20.5 \%)$ than for men, while in rural areas it is almost the same $(3.50 \pm 0.44$ for men and 3.55 \pm 0.44 for women). The second group can be observed in all cases to be significantly higher (by $24.4 \%$ ), especially among women (Table 3). However, in the third group, the opposite of this condition can be seen. Our attention was drawn to the fact that it was 3.8 times higher among the rural population than among the urban population, and 2.6 times 
higher among women. A number of features were also noted when examining the results of the analysis of newly diagnosed hypertensionrelated impairments by disability group. Of the total number of people with disabilities, $86.8 \%$ are group II and $13.2 \%$ are group III disabled, and it is noteworthy that group I disabled people are not registered at all. Looking separately at the most prevalent group II disability, in urban areas its prevalence is slightly higher for women (20.5\%) than for men, while in rural areas it is almost the same (3.50 \pm 0.44 for men and 3.55 \pm 0.44 for women).
The second group can be observed in all cases to be significantly higher (by $24.4 \%$ ), especially among women (Table 3). However, in the third group, the opposite of this condition can be seen. Our attention was drawn to the fact that it was 3.8 times higher among the rural population than among the urban population, and 2.6 times higher among women. Based on the above statistical analysis, the following can be summarized.

Table 7 Prevalence of total disability from blood pressure disorders in Khorezm province (10000 population) $(\mathrm{P} \pm \mathrm{m})$

\begin{tabular}{|c|c|c|c|c|c|c|c|}
\hline \multirow[b]{2}{*}{$\begin{array}{c}\text { Areas } \\
\text { surveyed }\end{array}$} & \multirow{2}{*}{$\begin{array}{c}\text { Persons } \\
\text { with } \\
\text { disabilities } \\
\text { (in } \\
\text { absolute } \\
\text { numbers) }\end{array}$} & \multicolumn{2}{|c|}{ Sex } & \multicolumn{3}{|c|}{ Disability groups } & \multirow[b]{2}{*}{ Total } \\
\hline & & Male & Female & I- group & II- group & III- group & \\
\hline $\begin{array}{l}\text { Urgench } \\
\text { city }\end{array}$ & 817 & $67,2 \pm 3,13$ & $52,1 \pm 2,73$ & $1,6 \pm 0,34$ & $49,7 \pm 1,90$ & $8,1 \pm 0,76$ & $59,6 \pm 2,08$ \\
\hline $\begin{array}{c}\text { Yangibazar } \\
\text { district }\end{array}$ & 676 & $141,0 \pm 4,82$ & $66,2 \pm 3,40$ & $0,6 \pm 0,04$ & $93,8 \pm 2,44$ & $9,2 \pm 1,50$ & $103,6 \pm 3,96$ \\
\hline $\begin{array}{c}\text { Khazarasp } \\
\text { district }\end{array}$ & 750 & $68,3 \pm 3,03$ & $32,5 \pm 2,07$ & $1,2 \pm 0,28$ & $47,5 \pm 1,78$ & $1,4 \pm 0,30$ & $50,2 \pm 1,82$ \\
\hline Middle & 748 & $92,46 \pm 3,66$ & $50,26 \pm 2,73$ & $1,13 \pm 0,22$ & $63,6 \pm 2,04$ & $6,23 \pm 0,72$ & $71,1 \pm 2,62$ \\
\hline
\end{tabular}

As it can be seen from the table, the average general disability from diseases of arterial pressure is marked in men $(92,46 \pm 3,66)$ in 1,8 times higher than in women $(50,26 \pm 2,73)$, especially this indicator in Yangibazar district in 2,1 times. Of the total number of registered invalids $-89.4 \%$ are registered as disabled persons of the second group, i.e. those who have completely and permanently lost working capacity. This situation amounted to $98.5 \%$ in Yangibazar district and $94.6 \%$ in Khazarasp district. 
The American Journal of Medical Sciences and Pharmaceutical Research

(ISSN - 2689-1026)

Published: September 29, 2021 | Pages: 79-89

Table 8 The prevalence rate of general disability from arterial blood pressure disease in the region by the age of patients (10000 population) $(\mathrm{P} \pm \mathrm{m})$

\begin{tabular}{|c|c|c|c|c|c|c|c|}
\hline \multirow{2}{*}{$\begin{array}{c}\text { Areas } \\
\text { surveyed }\end{array}$} & \multirow[b]{2}{*}{ Sex } & \multicolumn{6}{|c|}{ Young people } \\
\hline & & $\begin{array}{l}\text { Up to } 20 \\
\text { years old }\end{array}$ & $21-30$ & $31-40$ & $41-50$ & $51-60$ & $60<$ \\
\hline \multirow{2}{*}{ Urgench city } & Male & - & $2,7-$ & $6,0 \pm$ & $107,8 \pm$ & $519,0 \pm$ & $289,6 \pm$ \\
\hline & Female & - & $1,8-$ & $15,7 \pm$ & $194,0 \pm$ & $404,6 \pm$ & $41,9 \pm$ \\
\hline \multirow{2}{*}{$\begin{array}{c}\text { Yangibazar } \\
\text { district }\end{array}$} & Male & - & - & $8,7 \pm$ & $904,1 \pm$ & $590,9 \pm$ & $319,8 \pm$ \\
\hline & Female & - & - & $36,9 \pm$ & $367,9 \pm$ & $376,5 \pm$ & $14,6 \pm$ \\
\hline \multirow{2}{*}{$\begin{array}{c}\text { Khazarasp } \\
\text { district }\end{array}$} & Male & - & $5,9 \pm$ & $8,1 \pm$ & $155,0 \pm$ & $481,6 \pm$ & $279,2 \pm$ \\
\hline & Female & - & $4,9 \pm$ & $8,5 \pm$ & $207,6 \pm$ & $271,9 \pm$ & $27,8 \pm$ \\
\hline \multirow{2}{*}{ Middle } & Male & - & $4,3 \pm$ & $7,6 \pm$ & $388,9 \pm$ & $530,5 \pm$ & $296,2 \pm$ \\
\hline & Female & - & $3,35 \pm$ & $9,36 \pm$ & $196,5 \pm$ & $351,0 \pm$ & $28,1 \pm$ \\
\hline
\end{tabular}

As can be seen from the data presented, it was found that general disability from arterial blood pressure was found to have the characteristic of disability increase with age increase both in males and females in all studied regions, and its highest rate was observed in almost all social groups at the age of 51-60 years and its average rate was 440,7 This figure was equal to $-461,8 \pm 3,35$ in Urgench city, in the Newbazar district $-483,7 \pm 3,15$ and in the Khazarasp district $-376,7 \pm 3,3$. It was noted that after the age of 60 in all regions and social groups, General disability has the property of a sharp decrease, depending on the level of quality of living of patients. Based on the results of the above analysis, it is possible to conclude the following.

\section{CONCLUSIONS}

1. According to the information given in many literature sources and statistical data for the following years, the level of arterial blood pressure reference population in many developed countries, including our country, as well as in the Khorezm region, where our study is conducted, has the property of growth and rejuvenation.

2. Was found to be 1.7 times (75\%) higher in the rural population than in the urban population, and higher in the rural population compared to cases of untimely implementation.

3. The highest rate of referrals was seen in the 50-59 age group, accounting for 33.4\% of total referrals. $87.6 \%$ of the referrals were made by adults over 40 years of age, and the incidence decreased due to the effect of living beyond 60 years of age. 
4. $55.8 \%$ of the applicants were men, $20.7 \%$ more than women. More than half of the patients (55.1\%) had grade II blood pressure. It was found that $44.3 \%$ of the applicants had been hospitalised and treated.

5. According to numerous literature and statistics, the circulatory system as well as the prevalence of hypertension and disability from it tend to increase and rejuvenate in many developed countries, including our country and even the Khorezm region, where we are conducting research, in the later periods;

6. Newly diagnosed disability from hypertension accounts for $30-31 \%$ of the total number of re-disabilities due to circulatory disease, and its prevalence is significantly higher in women compared to men (17.1\%), especially in rural areas (43.3\%). There was no difference in location;

7. The majority of newly identified disabilities were found to be prevalent among the social group over 40 years of age, even across all population groups studied. (95,1\%). While both urban and rural disability was higher for women ( 4.3 times) than for men before the age of 39, there was little difference between the two after the age of 40;

8. No group I disability from hypertension has been redefined. It was found that $86.8 \%$ of the disabilities were in group II and $13.2 \%$ in group III, with group II accounting for the bulk of the disabilities. This circumstance acquired a similar character in all the populations studied.

\section{REFERENCES}

1. Akhmadalieva U.K. va boshkalar. (2016). Andijon shaxprining touli ax̧oli gurukhlarida arterial hypertension tarkalishini epidemiologik khususiyatlari. Jurnal.teorit.i klinicheskikh. Medicine. (2). pp.20-22.

2. Gadaev A.G. (2017). Organization of "School of Hypertension" - an effective method of raising awareness of the population about the risk factors of arterial hypertension and the transition to a healthy lifestyle. Cardiology of Uzbekistan.pp.26-28.

3. Faizullaev B.R. (2015). Study of prevalence of arterial hypertension among population of rural area of Khorezm region. Scientific-Practical Journal of CIS, Cardiology. vol.-III. 2. C.184.

4. Kurbanov R.D. (2011). Increasing prevention is the basis to reduce mortality from cardiovascular diseases in the Republic. Zbekiston Tibbiyot Journal, 3.pp. 61-69.

5. Malyutina S.K., Simonova G.I. (2013). Prospective study of the contribution of arterial hypertension to the risk of cardiovascular events, Bulletin co RAMS. 4.-Pp.6-10.

6. Turusheva Ye.A. (2017). Arterial hypertension in persons of conscription age: features of clinical treatment, diagnostic and therapeutic and preventive care in outpatient practice. Author's abstract of dissertation: candidate of medical sciences, Omsk.P.21.

7. Bortsova O.P. (2019). Occupational risk prevention of arterial hypertension in employees of high-tech engineering. Author's abstract of dissertation: candidate of medical sciences, Moscow. P.23. 
The American Journal of Medical Sciences and Pharmaceutical Research

(ISSN - 2689-1026)

Published: September 29, 2021 | Pages: 79-89

Doi: https://doi.org/10.37547/TAJMSPR/Volume03Issue09-14

8. Камалова, М. И., \& Исмоилов, О. И. Морфологические изменения сосудов микроциркуляторного русла головного мозга при геморрагичечом инсульте.

9. Ilkhomovna, K. M., Eriyigitovich, I. S., \& Kadyrovich, K. N. (2020). Morphological Features of Microvascular Tissue of The Brain At Hemorrhagic Stroke. The American Journal of Medical Sciences and Pharmaceutical Research, 2(10), 53-59.

10. Kamalova, M. I., Khaidarov, N. K., \& Islamov, S. E. (2020). Pathomorphological Features of hemorrhagic brain strokes. Journal of Biomedicine and Practice, 101-105. 